\title{
Afro-Chinese Labour Migration
}

\section{Obeng-Odoom, Franklin}

2021-07-03

Obeng-Odoom , F 2021 , ' Afro-Chinese Labour Migration ' , Forum for Social Economics, vol. 50 , no. 3 , pp. 276-296 . https://doi.org/10.1080/07360932.2020.1724554

http://hdl.handle.net/10138/338033

https://doi.org/10.1080/07360932.2020.1724554

cc_by_nc

acceptedVersion

Downloaded from Helda, University of Helsinki institutional repository.

This is an electronic reprint of the original article.

This reprint may differ from the original in pagination and typographic detail.

Please cite the original version. 


\title{
Afro-Chinese Labour Migration
}

\author{
Franklin Obeng-Odoom \\ Development Studies and Helsinki Institute of Sustainability Science \\ University of Helsinki, Finland \\ odoomj6@yahoo.co.uk
}

\section{Acknowledgements}

Many thanks to Dr. Wang, Professor Turok, and the reviewers of The Forum for Social Economics for very helpful feedback.

\section{Author Bio}

Franklin Obeng-Odoom is Associate Professor of Sustainability Science with Development Studies and the Helsinki Institute of Sustainability Science, both at the University of Helsinki in Finland where he is the current Chairperson of the Finnish Society for Development Research. He is currently completing a book titled, The Political Economy of the Global Migration Crisis (Oxford University Press, 2021).

\begin{abstract}
Labour migration is, perhaps, the most widely discussed economic issue today. Yet, its underpinning theory and its empirical tests have remained largely Westerncentric. In turn, the causes, effects, and policy options for the substantial, but widely neglected, Afro-Chinese labour migration, are poorly understood. By systematising existing data, this article shows that Afro-Chinese labour migration experience is far more complex than what neoclassical economics suggests. Driven, or, at least moulded, not so much by the migrant as a rational utility-maximising individual but by holistic processes of 'circular, combined and cumulation causation', Afro-Chinese migration, and Afro-Chinese relations, more generally, have contributed to economic growth, but at the cost of much socio-spatial displacement, and socio-ecological degradation. Added to these social costs is widespread labour exploitation. So, the insidious attempts by the state, business enterprise, corporate finance, and capital to consider migration as a 'spatial fix' for economic growth are questionable. Seeking to wall out migrants, embarking on widespread surveillance, pursuing migrant scapegoating, and framing migration as a Malthusian problem are, however, not a panacea. The social costs of migration need to be directly redressed, among others, by redesigning the institutions that shape the conditions of labour. Doing so would require leaving behind neoclassical economics theories of migration and exposing their vested interests. Social economics theories and theorising that more
\end{abstract}


comprehensively addresses the labour migration problematique and strongly emphasises the coupling of migration, economic, and social policy can usefully be considered as alternatives.

\section{Key Words = Migration, China, Africa, Social Economics}

\section{Labour on the Move}

Widespread global labour migration is, perhaps, the most discussed social problem today. According to neoclassical economists, it arises from real or perceived differences in wages across the world and the result of diverse returns on human capital between points of origin and destination (Todaro, 1969; Todaro and Smith, 2006; for a review, see Burnazoglu, 2017). Labour migrants, the argument continues, make rational choices based on expected income. So, they move when the actual or perceived prevailing level of income in the intended destination is much higher than their actual current levels of income.

These 'economic migrants', as they are usually called, are 'pushed' or 'pulled', by only material reasons but they are always better off after migration (Ravenstein, 1885,1889 ). In this process, unemployment is only frictional (see also a review by Pishé, 2013), the lack of assimilation temporary, and persistent inequality, transient. All these problems merely reflect differences in human capital or information asymmetry, which melt away with time. Indeed, based on a neoclassical interpretation called the 'Lewis Turning Point', the typical claim is that migration may cause inequality to rise initially, but as migrants earn more and more, inequality naturally reduces (for a detailed commentary, see Molero-Simarro, 2017). So, it is the effect of labour migration on growth and 'catch-up', which are the key criteria for judging its success (Clausing, 2019a, 2019b).

Typically associated with academic economists (e.g., Clausing, 2019a, 2019b) and economic journalists (The Economist, 2019a, 2019b, 2019c), such theories are also 
advocated by many prominent social scientists such as M.M. Gordon (e.g., Gordon, 1961) and many global leaders. This widespread influence of economic ideas recalls J.M. Keynes' famous statement that 'the ideas of economists...are more powerful than is commonly understood...Practical men, who believe themselves to be quite exempt from any intellectual influences, are usually the slaves of some defunct economist. Madmen in authority, who hear voices in the air, are distilling their frenzy from some academic scribbler of a few years back' (Keynes, 1953/1964, p.383).

Yet, these ideas lack consistent empirical verification. In the case of Afro-Chinese labour migration, a substantial and dynamic ${ }^{1}$ stream of labour migration, at least, these issues require investigation. The global literature on migration tends to focus on Europe and North America, while the emphasis of most Afro-Chinese studies is whether it could be regarded as 'the new scramble for Africa' (The Economist, 2019a). Questions about Afro-Chinese labour migration are less frequently discussed. There are many respectable exceptions (see, for example, Lee, 2014; Mohan et al., 2014; Sweetland and Edwards, 2019), of course, but they do not set out to engage the economics of labour migration.

However, in the light of the theoretical claims by neoclassical economists, other social scientists, and many global leaders, the existing rich pool of insight and ethnographic detail (e.g., Bodomo, 2012; Ozkul and Obeng-Odoom, 2013; Freeman, 2017; Whitaker, 2017;Park et al., 2016; Sweetland and Edwards, 2019. On compiling detailed cases of Chinese or African migration, see Manu, 2005; Chang, 2008; Ngai, 2016; Xu and Chen, 2019; Tonah et al., 2018) about Afro-Chinese labour migration can help to address, perhaps, the three most intractable questions about labour migration in political economy. First, why do African and Chinese labour migrants move to Africa and China? Second, what are the socio-economic effects of this Afro-Chinese labour migration? Third, how might migration policy more effectively address the process and consequences of labour migration?

By systematising existing data, this article shows that Afro-Chinese labour migration experience is far more complex than what neoclassical economics suggests. Driven, or, at least moulded, not so much by the migrant as a rational utility-maximising individual but by holistic processes of 'circular, combined and cumulation causation', Afro-Chinese migration, and Afro-Chinese relations, more generally, have contributed to economic growth, but at the cost of much socio-spatial displacement, and socio-ecological degradation. Added to these social costs is widespread labour

\footnotetext{
${ }^{1}$ Various studies suggest that the size of Chinese migrant population in Africa increased from 80, 000 to over 750000 between 1980 and 2006 (Ancharaz, 2011; Mohan et al., 2014, pp. 3-6). More recently, these migrants are estimated to be between one and two million people (see, for example, French, 2014, p. 26; Bodomo and Ma, 2010, p. 286). They work in a wide range of sectors, from mining and small-scale manufacturing to trading. The population of Africans in China is much less but substantially never the less. Currently, there are nearly 500, 000 people (Bodomo and Ma, 2010, pp. 283-284), that is, about half the size of the Chinese population in Africa, who live in China. These Africans work in various professions, including education, diplomacy, and entertainment. Guandzhou is the single most important place of settlement for African migrants. It is estimated that, alone, Guandzhou hosts 130, 000 Africans (Lee, 2014, p. 20). The rest live in cities such as Yiwu (Cissé, 2015, p. 50).Much has also been written about the estimated 150, 000 Chinese professionals who were sent to Africa to work in the agricultural, transport, and telecommunications sectors in the 1960s and the beginning of the 1980s (see Mung, 2008, p. 95) but, today, the range of activities in which Chinese migrants are involved is much wider. For example, it is estimated that there are between 700 and 800 Chinese companies in Africa, operating in 49 out of the 54 countries on the continent. Together, these companies employ about 80, 000 Chinese workers (see Mung, 2008, p. 95).
} 
exploitation. So, the insidious attempts by the state, business enterprise, corporate finance, and capital to consider migration as a 'spatial fix' for economic growth are questionable. Seeking to wall out migrants, embarking on widespread surveillance, pursuing migrant scape-goating, and framing migration as a Malthusian problem are, however, not a panacea. The social costs of migration need to be directly redressed, among others, by redesigning the institutions that shape the conditions of labour. Doing so would require leaving behind neoclassical economics theories of migration and exposing their vested interests. Social economics theories and theorising that more comprehensively addresses the labour migration problematique and strongly emphasises the coupling of migration, economic, and social policy can usefully be considered as alternatives.

To illustrate these arguments, the rest of the article is divided into four sections. Circular, Combined, and Cumulative Causation analyses the causes of labour migration. The Social Costs of Growth probes the growth-inducing effects of migration, and its social costs. Migration Policy examines how migration policy attempts to address these tensions and contradictions, while Conclusion: Retheorising the Economics of Labour Migration attempts to retheorise labour migration. 


\section{Circular, Combined and Cumulative Causation}

Labour migration is driven by forces of circular and cumulative causation; not just by what mainstream economists call 'opportunities' (World Bank, 2017). Business cycles are, of course, important as drivers of migration, as J.R. Commons (1907) famously argued. Typically, booms attract migrants, while depressions repel them. Yet, these business cycles occur within a wider social environment over a long period of time, as the evidence systematised in figures $1 \mathrm{a}$ and $1 \mathrm{~b}$ illustrates. Consider what Commons (1907, pp. 12-13) described as 'colonial migration'. Such labour migration is not driven by migrants' rational calculations or their interest in business at all. Instead, some 150,000 Chinese were sent to Africa in the nineteenth and twentieth centuries as indentured labour (Yoon, 2019, p.92). They did not freely choose to move. They were coerced. In Madagascar, the French led the way: using Chinese convicts as conscripts to advance French imperial interests (Treman, 2013). The Dutch, British, Portuguese and many others put Chinese labourers to similar uses in the rest of Africa (Park, 2019). Many of those who won their freedom stayed on, as did many of their descendants (Duyvendak, 1945; New African Magazine, 2015; Park, 2019).

These historical reasons provide a context for analysing the causes of labour migration, but they also create path dependencies, as demonstrated by historians (Hobson, 2004;Akyeampong, 2011). Figure 1(a) shows three time periods that are particularly important to develop this line of analysis.

(a) Historical Forces

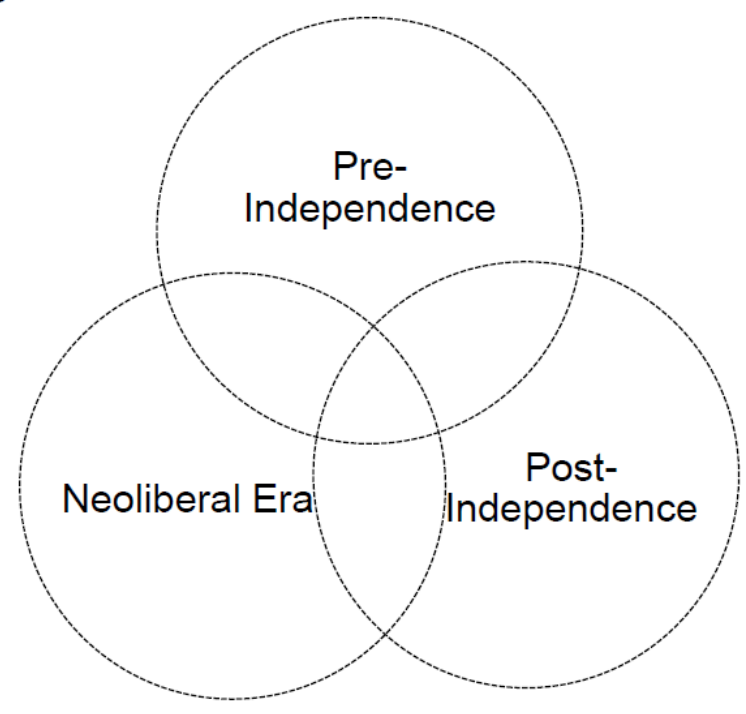


The reign of Mao Tse-tung (1949-1976) constitute phase one. The rise of Deng Xiaoping (1978 - 1992), phase two, and the period thereafter (post 2001), phase three. These three epochs parallel the emphasis on internal self-sufficiency, the loosening of internal economic restrictions supplemented with the efflorescence of China as an important global player, and the rise of China as a global force typified, among others, by China's acceptance of rules by the World Trade Organisation. In Africa, these periods also roughly collocate with pre-independence and the colonial period, independence, and post-independence epochs. Pre-independence developments were important. The 1955 Bandung Conference embodied the collective aspirations of the Global South to break the chains of colonialism. African leaders such as Kwame Nkrumah helped to foster South-South co-operation, which often provide the context for migration analysis (see Amoah, 2019 for a detailed account of Nkrumahist strategies to promote Ghana-China relations).

The path dependency created by this early history of migration is striking. The migrants who stayed in Africa directed new comers to various parts of the continent where these new migrants could settle more comfortably. Indeed, early Chinese migrants in Mauritius influenced the decision of many South African-based Chinese migrants (Yoon, 2019, p.94). Also, as many of these early migrants exported local African goods to China (Yoon, 2019), it is plausible that such trade, together with other factors, shaped the drivers of Chinese migration to Africa. This is not prima facie evidence that Chinese migration to Africa was for opportunity. Many migrants created their own opportunities. This creative response, to use Joseph Schumpeter's framing (Shumpeter, 1947) challenges the neoclassical labour economics fixation on adaptive response to take rather make opportunities.

Of course, the more recent turn to neoliberalism has strongly shaped the discourse on 'opportunities' (Hiafang, 2010; Cheru and Obi, 2010), although this rhetoric is at the national level and its theory of entrepreneurship is not as holistic as Schumpeter theorised it (Schumpeter, 1947). Most African states court Chinese economic engagement, while China is seeking to consolidate its own economic and political standing in the global community by courting African engagement. Accordingly, Chinese support to Africa is not entirely in solidarity terms. It is also to promote mutual economic interests. In 2000, Beijing voluntarily waived Africa's $\$ 1.2$ billion sovereign debt to China. In return, between 2000 and 2005, the value of AfricaChina trade increased more than four times. Crucially, since 2000, every year, more Chinese entrepreneurs have moved to Africa. In 2006, the number was ten times higher than what pertained in 2003 (Arrighi, 2008, p. 207). Today, an estimated 10, 000 Chinese businesses have been established in Africa. In monetary terms, China's FDI in Africa has grown substantially. Between 2011 and 2016, Chinese FDI in Africa grew from $\$ 16$ to $\$ 40$ billion (The Economist, 2019d, pp. 18-20). Most of these investments influence Chinese labour migration to Africa (Ramamurti and Hillemann, 2018, pp. 43-44; McVeigh and Dzradosi, 2019). Alone, the Chinese state has exported more than 80,000 Chinese labour migrants to work on Beijing-funded FDI projects. At least 80,000 of these migrants have plans of continuing to live in 
Africa (Hilson et al. 2014, p. 296). Not only do these state initiatives create opportunities for small-scale Chinese businesses, Chinese businesses (e.g., roads, fishing, or mining) also largely recruit Chinese workers, much like a few African businesses (Park, 2019).

This Chinese path to Africa is even more striking in the context of state restructuring in China. After retrenchments in public sector jobs led to 60 million job losses in China in the mid-1990s and the lowering of the conditions of labour (Bieler and Lee, 2017 , p. 4), Chinese workers demonstrated what Karl Polanyi (1944/2001, p. 79), described as a 'double movement'. Specifically, 'the extension of the market organisation in respect to genuine commodities was accompanied by its restriction in respect to fictitious ones'. The number of worker strikes increased consistently. The number of strikes in 2005, for example, was eight times higher than what pertained in 1993 (Arrighi, 2008, p. 377; for recent data and analyses, see Molero-Simmaro, 2017; The Economist, 2019e). However, migration to Africa appears to have become the other path to the double movement.

The emergence of a new Chinese financial architecture in China facilitates this institutionalised alternative (Cheru and Calais, 2010; Cheru and Obi, 2010; Sanderson and Forsythe, 2013; French, 2014; Sheridan, 2016; Robertson, 2016). Consider the activities of institutions such as China Development Bank, Exim Bank, and Industrial and Commercial Bank of China. Their lending terms tend to include the employment of Chinese and the creation of conditions that support the further development of the conditions that would support the efflorescence and flourishing of Chinese businesses in Africa. Even when these banks themselves do not impose such conditions; Chinese businesses have tended to hire Chinese labour. These institutions do not necessarily take instructions from the Chinese state. They are private initiatives intent on making China both the world's factory and the world's supplier of cheap labour (Bieler and Lee, 2017).

Thus, in explaining the drivers of migration, it is what J.R. Commons called 'institutionalised mind' that mattes. In his words:

If it be considered that, after all, it is the individual who is important, then the individual with whom we are dealing is the Institutionalized Mind. Individuals begin as babies. They learn the custom of language, of cooperation with other individuals, of working towards common ends, of negotiations to eliminate conflicts of interest, of subordination to the working rules of the many concerns of which they are members. They meet each other, not as physiological bodies moved by glands, nor as 'globules of desire' moved by pain and pleasure, similar to the forces of physical and animal nature, but as prepared more or less by habit, artificial transactions created by the collective human will. They are not found in physics, or biology, or subjective psychology, or in the German Gestalt psychology, but are found where conflict, interdependence, and order among human beings are preliminary to getting a living. Instead of individuals the participants are forces of a going concern. Instead of forces of nature they are forces of human nature. Instead of isolated individuals in a state of nature they 
are always participants in transactions, members of a concern in which they come and go, citizens of an institution that lived before them and will live after them (Commons, 1934a/2009, pp. 73-74).

(b) Personal Factors

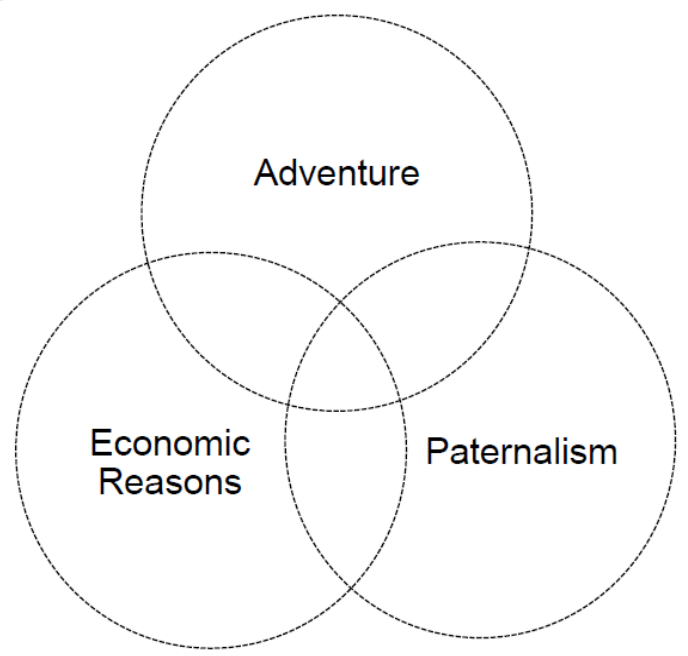

While personal factors (figure 1b) and migrant agency can be named as part of the drivers of Afro-Chinese migration, but they are also shaped by family and other reasons (Ho, 2012; Mohan et al., 2014; Rosewarne, 2010, 2012, 2014, 2016; Castles, 2011, 2012, 2015). The experience of many Chinese women migrants in Africa is a case in point. Many of these single, divorced, and less educated women consider family pressure to remarry burdensome. Combined with wider social expectations in China, migrating to Africa is institutionally and socially constructed as an alternative pathway (Mohan et al., 2014, pp. 71-72, see also pp. 80-81; see Mohan et al., 2014, pp. 81-83; Cissé 2015).

African migration to China confirms this circular and combined causation of migration. The Nigerians who send an estimated \$8million daily to Guangzhou for business transactions (Lee, 2014, p. 32) are driven by a panoply of factors. Differential cost of production between Nigeria and China is one of them. The prevalence of duty-free regulations that apply to goods exported from China is another (Lee, 2014, p.34). The limited opportunity for public sector employment in Nigeria is a third factor. Other African migrants first went to China as students. They became labour migrants during or after their studies through a mosaic of reasons. Consider the social spaces that their education in China opened and inter-marriage. These are not necessarily related to business cycles. So, their decisions are shaped by other factors (figure 1c) than what initially motivated them (figure 1b). 
(c) Combined and Cumulative Causation

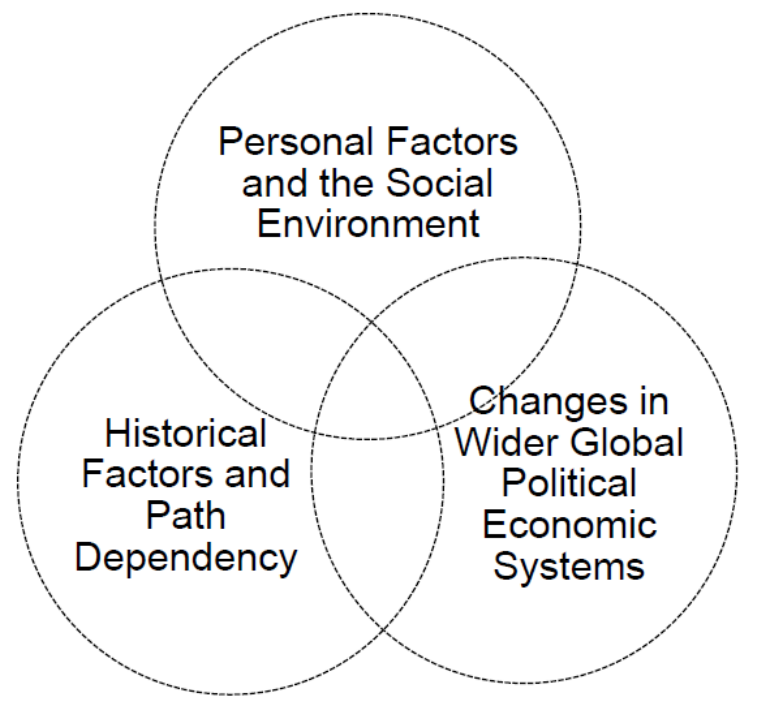

A circular, combined, and cumulative process is at play in all these examples. After the completion of cycles, the next round is not the same. It generates additional forces that drive the migration process. That is how the networks and the social provisioning in the migration process have arisen and are maintained (Tinti and Reitano, 2017). Facilitators of the journey are usually described as 'people smugglers' in the Anglo-Saxon literature. However, their role is far more complex because they are neither just smugglers nor just saviors. They can be both at different times and neither at other times, especially when they are sometimes migrants themselves. Indeed, they can also be all of these identities at different times (Tinti and Reitano, 2017).

The experiences of internal African migrants in Senegal can further illustrate the point. In an economy with few political-economic options, these migrants hire themselves out at much lower wage rates. Chinese shop owners usually hire them to run their shops in Dakar. These desperate Senegalese migrants typically have no work contracts and are quite often fired without due process (Cissé, 2013). Promised a better life, these poor people may migrate for economic, but also other, reasons. This social economics of migration recalls how migrants from elsewhere in Accra straddle the formal and informal economies (Hart, 1973; Obeng-Odoom, 2011; Ndjio, $2009,2014)$. In this process, other complexities arise that become part of the cycle, even if they were absent in earlier drivers. 
Consider, the Asian Financial Crisis of 1998. It heralded changes in local but also wider global political economic systems. Many Africans from Indonesia and Thailand moved to new areas in Asia for these reasons. Guandzhou was one of their major destinations (Lan, 2015, p. 292). A migrant town, its allure to new migrants signal that migration decisions are shaped by path dependencies. Yet, these paths can be broken, for example, through the implementation of new laws. The Guangdong Provincial Government's anti-migration law (Guangdong Act) is a case-in-point. This law rewards Chinese for reporting Africans who may have overstayed, those who enter China illegally, or are involved in any illegality, while punishing Chinese who refuse to do so (Lan, 2015). In contrast, in Yiwu, the trading city in the Eastern Province of China, the legal regime is characterised by programs initiated and maintained by its local leaders to support African migrants. Keen to boost the urban economy of Yiwu, these leaders seek to attract migrants by creating the institutional context that makes Yiwu a welcoming city for Africans. The city authories provide municipal services to suit its African community (see, for example, Bodomo and $\mathrm{Ma}$, 2010), for example. Consequently, while Guangzhou has lost many of its African labour migrants, between 2006 and 2009, the number of registered Africans in Yiwu increased from 20,311 to 54,050 (Cissé 2015, p. 50 ). Clearly, migration is a socially embedded process whose drivers act like a relay-race. The processes and networks associated with the experience cannot entirely be described as economic or noneconomic. As a socio-economic process, various forces drive diverse activities or run their part of the race.

Illustrating that circular, combined, and cumulative causation processes; not utilitymaximising rational choices, drive Afro-Chinese migration shows a lack of congruence between neoclassical economics theory and social reality. Although problematising the mainstream is important in its own right, the analysis, however, shows more than simply telling 'right' from 'wrong'. It also suggests that Afro-Chinese migration has historically been part of wider social change. In turn, categorising labour as 'economic migrants' is quite arbitrary. More fundamentally, the drivers of migration are not just about income differences. They are, even more crucially, about wider conditions of work and general prevailing socio-economic environment internally, internationally, and globally. If migration appears quite historical, is widespread, and is a matter of right because we have one earth given to us as a gift, then migration can be facilitated. Doing so, however, for the promotion of capitalist expansionism, the cheapening of labour and its products, as well as persistent and relentless economic growth, as advocated by mainstream economists (Claussing, 2019a, 2019b; The Economist, 2019a, 2019b, 2019c) as a win-win strategy, however, is questionable. The effects of widening growth on the environment (Daly, 2019) is catastrophic, as are the other social costs of growth.

\section{The Social Costs of Growth}


Chinese migrants in Africa make substantial contributions to African economic growth. Much of this growth is job-led. Consider the establishment of Chinese enterprises in Africa. One estimate is that entrepreneurs from China have created some 300, 000 jobs for African workers (Mutethya, 2018). The contribution of African labour migrants to urban economic growth in China is similarly substantial. Guangzhou was an industrial city (Hobson, 2004; Akyeampong, 2011) whose economy has now been diversified by the economic activities of African migrants. According to Jane Jacobs' (1969) epigenesis theory, activities such as trade transform the local economy. Exports bring in revenue which, in turn, generates further urban economic activities. Growth comes not only from these activities themselves but also from their clustering, which generate agglomeration economies. The agglomeration of different people also produces advantages. Alfred Marshall described them as knowledge, input, and labour sharing among various firms and economic entities working in the urban economy (Obeng-Odoom, 2016, pp. 83-106). These advantages spill over to surrounding areas. So, spatial proximity leads to what economists call 'spatial externalities' (Bara et al., 2017). More fundamentally, migrant entrepreneurs themselves innovate by doing new things or old things in new ways. Even if these innovations are quite ordinary, as Joseph Schumpeter demonstrated, such entrepreneurship drives substantial economic change (e.g., Schumpeter, 1947). This Schumpeterian theory of interdependent and evolutionary change is reflected in more recent experience.

As one Chinese entrepreneur observed in a study by Lan (2015, p. 297), '[w]e depend on Africans for business. If our government does not allow them to come, we have to close our shops'. More recently, many of the Chinese interviewed in Erica Marcus' research documentary Guangzhou Dream Factory (Marcus, 2017) admitted on camera that they are in business because of African labour migrants. As many Africans cannot operate legal bank accounts by themselves, they rely on new banking forms operated by Chinese residents. Money exchange is another business, usually led by Chinese migrants from Northern China (Lan, 2015). Most Africans in China are quite well-educated, so they bring valuable skills to Chinese cities. Africans teach Chinese and also succeed in employing Chinese in successful businesses that they run in China, a finding that challenges the view that Africans are lazy workers and are incapable of entrepreneurial success (Mohan et al. 2014). Thus, Afro-Chinese labour migration has made various contributions to growth.

The social costs of this circular, combined, and cumulative economic growth have also been substantial. Migrants live a life of uncertainty, a reality which, according to J.K. Galbraith, contrasts with the certainties of economic theory, capitalism, and socialism (Galbraith, 1977, p.7). Not only do many migrants fail in business, others live a life of uncertainty and insecurity, sojourning as temporary migrants on yearly residency permits (see Lee, 2014, pp. 29, 33). Migrants' bi-racial, Afro-Chinese families face widespread racism and ostracism at school and at work. They become, as Robert Coles (1971) famously theorised, 'children of crisis'. The local 'growth machine' (Molotch, 1976) that generates economic boom in migrant towns based on iterative and interactive networks and interactions with locals and institutions (Obeng-Odoom, 2016, pp. 83-106; Saunavaara, 2017; Wang and Giovanis, 2019) 
also creates major problems. A local property market is called forth by the activities of African migrants, but Chinese landlords extract significant rent by either letting or subletting their shops to Africans. This stream of rental payment enables landlords to live as rentiers, capturing rents which are socially created.

Africans may appear to be winning. After all, the stereotypical view is that many African states have not created as many jobs in the public sector. Instead, their rhetoric of 'urban governance' and, hence, of attracting private initiatives seems to be met by increasing Chinese investment (Obeng-Odoom, 2013). Yet, many locals have become tenants on their own land. As local land has been leased to Chinese investors to develop shops, many of which recruit Chinese workers, many ordinary Africans have faced persistent insecurity of tenure. Sometimes too African tenants are forced off to find alternative shops or housing because they are priced out of new property markets that arise from Chinese property investment. The boom-bust cycles in property markets instantiated by speculative urban development creates uncertainties, while the increases in land prices, arising from the construction of expansive road networks, generate insecurities from increasing property prices.

That is evidently the experience of Angolans in Luanda. Chinese speculative urban development in Angola and its financing have created spatial and social inequalities as well as widespread uncertainties especially in Luanda and Kilamba City. One indication of the scale of speculation is that apartment prices, previously pegged at US $\$ 120,000$, dropped to US $\$ 84,200$ for want of effective demand. Even then, locals have been priced out of housing, leading to the concentration of the wealthy in centralidades (Cain, 2014; Watson, 2014). Similar comments apply to the experiences of other African countries. While many Africans have been recruited by Chinese businesses in Rwanda, where China Civil Engineering Construction Corporation and New Century Developments has a branch (Lee, 2014, pp.97-98), many Africans work under difficult labour conditions, much like Chinese workers. This cheap and precarious labour is extracted in a process that stirs widespread ecological costs.

The experiences of small-scale Chinese miners can help to illustrate the point. Many of these miners have left Shanglin gold mining town in China because of the depletion of gold in China (Mohan et al., 2014, pp. 98-99). They have been drawn to Ghana by private labour contractors operating both in China and Ghana, including Shaanxi Mining (Hilson et al., 2014, pp. 300-301). Generally, the operations of these migrant miners in Africa have contributed to major ecological degradation (Beck, 2012; Mohan et al., 2014, p. 99; Hilson et al., 2014; Obeng-Odoom, 2017). In Ghana, 'a burgeoning illegal Chinese mining population has re-routed rivers and flooded roads used by villagers to access markets, seized farmlands unscrupulously, and bulldozed moats constructed for agriculture' (cited in Hilson et al., 2014, p. 292).

In such a situation, it is tempting to seek arrests of Chinese migrant miners themselves, but such a focus neglects an important dynamic. Most of these migrants are Chinese minorities, including members of Zhuang, a marginalised people in China. As Chinese 'untouchables', these migrants' uncertainty is heightened in Africa, where they live a life of insecurity. They feel unsafe, and are recurrently 
attacked as victims of scapegoating. While they make some money from mining, they use much of this money to support their poor and indebted families and communities in China (Botchery et al., 2019, pp. 313-316). Often, these migrants are also exploited and are reliant on networks that capitalise on, and reinforce, systems of inequality. These social conditions cannot excuse their pillaging of the environment, but their actions and inactions must be contextualised to purge it of claims about Chinese peculiarities. The identities of facilitators or 'middlemen', for example, must be a focus of analysis too.

Chinese migrants do not act alone. They are supported by ordinary Africans, politicians and local leaders. This local network facilitates the process of transferring collectively-held land into individual migrant ownership. Transnational corporations (TNCs) are also involved in this process. Their environmental footprint is colossal. According to the Minister for Environment, Science, Technology and Innovation, it would cost Ghana US $\$ 650$ billion to reclaim the environment degraded by the combined and cumulative effects of illegal, migrant heavy mining' and the activities of TNCs. The 'social costs' (Kapp, 1950/1971) are likely to be much bigger (see, for example, Le, 2016). The difficulty is that such identities are evolutionary because some of them used to be exploited migrants too, as Peter Tinti and Tuesday Reitano (2017) demonstrate in another context.

Still, these networks arise from, and are maintained through, inherent forces of inequality and uncertainty which, in general, have largely been considered to be central to social costs under capitalism (Kapp 1950/1971; Ramazzotti et al., 2012). J.R. Commons (1907) offered one possible explanation of why they exist. As a key driver of migration is the business cycle, Commons used such networks to illustrate how inherent inequality can be in the migration process. In contrast to neoclassical argument that migration always pushes prices down, Commons argued that it can also cause the prices of goods and services to increase. As immigration causes the size of population to grow, blatant or disguised protectionism can make population size outstrip the volume of goods and services. As wages are pushed down because there is more labour available than what is socially necessary to maintain production, profit levels can be expected to rise dramatically; not just because of rising prices but also because of falling cost of production. The effect of migration, then, is to concentrate wealth in the hands of capital.

A similar explanation can be used to show how this process concentrates rent in the hands of landlords. The sudden injection of money from migrant mining increases land values. This escalation of value is not just from demand, but also from speculation (Obeng-Odoom, 2014; Botchwey et al. 2019). The cost of living rises, further raising rental levels. The switch in the uses of land from agrarian to mining and oil drilling creates similar effects: increasing land values and concentrating their resulting rents in the hands of landlords.

Added to these explanations is the problem of dumping. Chinese exports to Africa have paralysed many indigenous textile industries in Africa. These cheap mass- 
produced imitations of local goods close jobs available to local labour. Dumping also devalues labour. Workers imported from China hire themselves out at much lower labour standards than are locally permitted (Mung, 2008; Akorsu, 2010, pp. 206207). With the increasing tendency to import Chinese labour (see, for example Obeng-Odoom, 2015), there is a tendency for this practice to force down already low prices and lower labour standards in Africa. Similar practices apply among African employers in China who exploit the lower cost of labour in China. Many African merchants also partake in this 'dumping'. This Fordist production processes leads to the mass and cheap production of African needs which, the Chinese have come to understand, while collaborating with some African traders (Ho, 2012). In turn, the profit levels of producers and employers both in Africa and China have increased substantially, followed by the declining conditions of work. This evidence (e.g., Aidoo, 2010; Tremann, 2013; Obeng-Odoom, 2017) bears out early predictions by J.R. Commons (1907) that dumping could (1) increase the price of goods and services, (2) reduces in wage levels and (3) raise profit levels.

These social costs metastasize into ecological costs. Consider the environmental footprint of Chinese labour migrants who work illegal fishing and illegal mining towns in Ghana (e.g., Hilson et al., 2014; McVeigh and Dzradosi, 2019). Chinesedominated Illegal trawling has not only led to the loss of $\$ 65$ million to the people of Ghana (McVeigh and Dzradosi, 2019, PP. 26-27), it has set into motion a process of over fishing. Also, through their use of toxic chemicals such as mercury, many water bodies and farm lands have become contaminated and incapable of supporting biodiversity and human livelihoods. Biodiversity has declined, injuries have multiplied, and many human lives have been lost, as a result of the activities of these migrants (Wilson, 2015, p. 9).

Such social and ecological costs existed prior to the involvement of Chinese migrants, of course. However, systematic fieldwork (Thornton, 2014, Hilson et al., 2014; Wilson, 2015) shows that the advent of Chinese involvement in mining in Ghana has dramatically increased the problems. The more advanced technology utilised by these migrants enriches productivity considerably. Through expanded production, they also generate worse environmental outcomes. More pits can be dug shortly, more trees destroyed quickly, a greater number of animals killed more efficiently, and larger doses of mercury dispensed off more rapidly. Yet, the widelyheld view that Chinese migrants are at the forefront of this systematic ecocide and the production of inequality and social problems must be problematised. Indeed, migrants from other parts of Ghana and other countries in Africa are complicit too.

Their use of traditional, manual methods of mining (which are less efficient and less brutal in their effects on the environment), might extend the time during which their ecological footprint can be seen, but they are still environmentally damaging. Other groups us more mechanised methods. Such is the case with labour migrants from Canada, from Portugal, Russia, and Spain, from India, the UK, and the USA who use even more high-tech mining equipment whose damaging effect on the environment is documented (Wilson, 2015, p. 10). Indeed, the many transnational 
mining corporations with large and generous concessions and benevolent tax breaks that control the mining sector in Ghana are much worse culprits.

This evidence helps to see the limits of recent debates about the role of the state in migration policy. Nationalists sentiments drive the erection of walls, while border studies advocate their removal (Lemberg-Pedersen, 2016), humanists prefer the win-win trope of temporary migration, integration, and eventual 'return' (ObengOdoom, 2017). Yet, as the analysis of Afro-Chinese labour migration shows, the role of the state needs to be more carefully analysed.

\section{Migration Policy}

If Afro-Chinese labour migration is characterised by uncertainty, inequality, and unsustainability, it is important to revisit the relevance of the two questions typically asked about Afro-Chinese labour migration policy (Cheru and Obi, 2010; Lee, 2014; Amoah, 2014, 2019): Do African states have clearly designed labour migration policy for China? and What about the Chinese state: does it have such a policy?

Not only are these questions irrelevant, their responses are also misleading. The claim that Africa has no Chinese policy, indeed that African states have little or no border control policies is one such response. According to Margaret Lee (2014), not only is there a lack of policy but there is also a lack of co-operation among African states when working with China. For instance, in its dealings with illegal Chinese labour immigrants, Margaret Lee claims, the Ghanaian government fails to collaborate with the Togolese authorities, although doing so is important to better understand how some Chinese pivot to Ghana from Togo (see Lee, 2014, p. 99). Another response is that Chinese 'Go Out' policy is the Chinese state's approach to encourage emigration from China, while it has a policy of 'complete control' of migrants within its borders (Graham-Harrison and Garside, 2019).

These positions are questionable. As Ellen Brennan's (1984) work has shown, both China and Africa seek to restrain migrants in their territory through border controls and labour market regulations about work permits (Brennan, 1984). So, the requirement for work permit is one way of controlling migrants. Both China and countries in Africa also institutionalise uncertainty by making Afro-Chinese labour migrants temporary. Most of these migrants hold temporary visas. It is rare to find permanent African residents in China or, say, permanent Chinese residents in Ghana. Both often have punitive regulations against employers of irregular migrants and often some reward system for people who report illegal migrants. Even worse, both the Chinese and African states adopt expulsion and widespread surveillance of migrants. For example, like what pertains in China, in Ghana, the state raids markets to confiscate cheap Chinese textiles that are imitations of Indigenous Ghanaian prints, using a nationalist discourse to promote a 'Friday Wear' of only Indigenous textiles, and issuing a fiat that all imports of 'African' textiles ought to go through one port to improve the effectiveness of monitoring (Axelsson, 2012). The Ghanaian state also recurrently prosecutes and deports Chinese migrants whose equipment is also confiscated, as shown in table 1. 
Table 1: Ghanaian State Control of Chinese Migrants, 2010 - 2018

\begin{tabular}{|l|l|l|l|}
\hline Years & Prosecutions & Deportations & $\begin{array}{l}\text { Pieces of Equipment } \\
\text { Confiscated }\end{array}$ \\
\hline $2010-2013$ & & 4,500 & - \\
\hline $2013-2016$ & 1,405 & - & - \\
\hline $2014-2017$ & - & 734 & - \\
\hline $2016-2017$ & 701 & - & - \\
\hline $2017-2018$ & & & 18,593 \\
\hline Total & 2,106 & 5,234 & $18,593^{*}$ \\
\hline
\end{tabular}

Source: Adapted from Debrah and Asante, 2019, p. 297

* Excavators (1,834); Water pumps $(3,100)$; Vehicles (242); Motor bikes (238); Changfa mining machines used for crushing solids $(13,179)$.

The effectiveness of these approaches is questionable both in Africa (Hilson et al., 2014) and in China (Lan 2014). More fundamentally, the typical responses systematically neglect the circular, combined, and cumulative causes of migration and the social costs that characterise it. The wider question of labour exploitation, the effect of unequal property relations on migration, and the resulting stratification from the social creation but the private appropriation of rent is similarly neglected. Focused exclusively on the state, without taking into account the wide-range of institutions that condition migration, both existing and proposed migration policies are founded on problematic assumptions. The sustained focus on Chinese racism against African labour, often used to justify Chinese exclusive employment practices (Lee, 2014), is understandable. However, it must be related to employer tactics to keep wages low, divide workers, and control them for the expansion of capital, as famously demonstrated by J.R. Commons (1907).

A new migration policy is needed, but a detailed exposition is beyond the scope of this paper. Its ingredients could include developing social regulation of current migration processes to facilitate rather than hinder it. As theorised elsewhere (Burnazoglu, 2017; Obeng-Odoom, 2017, 2018), the reason for supporting migration is largely based on the one earth argument: the idea that all humans have a right to freely given land by nature. This proposition strongly recognises the social costs of migration for which both social and economic policy can be carefully developed. For informal workers outside the realms of documentation, they could self-organise as co-operatives or unions. Doing so could provide social networks that can more easily negotiate and receive diverse institutional support.

The activities of such co-operatives could include (a) community development (b) ecological development to repair impairments arising from their activities and (c) helping to provide their members with social protection obtained from various institutions such as the state and all its geographical and functional arms. Indeed, these co-ops could propose minimum wage regulations in their areas of work and 
work with other groups to seek not just better conditions of work but also to work less.

Expansion of the public sector is crucially useful. The point is not to create more work, but to redistribute work such that those who are overworked could be relieved of their work. Re-activating the spirit of the Bandung conference, permanent residency status could more easily be extended to both African and Chinese migrants. In any case, it was Chinese indentured labour and the labour of black people that collectively strongly contributed to the development of infrastructure in Africa. The support of Africa, African states, and peoples to Chinese development is similarly monumental. Allaying mutual fears, uncertainties, and insecurities could be started by making migrants more permanents, guaranteeing their rights, and supporting their activities. Coupled with the expansion of social policy and the direct redress of the social costs of migration, including a land and housing policy that makes accommodating migrants far more decent in such a way that the conditions of labour are improved, this emphasis on making migrants permanent could more strongly support migrants. Examples from around the world, including Alaska and Singapore (see Haila, 2016; Obeng-Odoom, 2017) suggest that such policies are both possible and desirable.

\section{Conclusion: Retheorising the Economics of Labour Migration}

Migration research continues to grapple with key questions. Causation is one of them. It is closely associated with debates about migrant agency. The migrationeconomy nexus is a second, while a third question relates to labour migration policy. The critical questions are whether migration is driven by the utility-maximising rational calculations of migrants and in what ways migrants shape the economy. Whether it is through injecting more human capital, more trade, and more investment in the economy, the neoliberal theory is that immigration of skilled labour drives growth. Conservative critics similarly point to growth as the key test of economic progress, but contend that labour migrants reduce growth by taking jobs away from locals, depressing wages, and putting pressure on infrastructure. Thus, for mainstream economists, migration creates a 'spatial fix'. According to David Harvey (2006, p. 444), "[g]lobal freedom for the movement of capital (in all forms) has allowed instant access to the 'spatial fix' through geographical expansion within a framework of uneven geographical destruction". Africa is a 'spatial fix' for China's internal problems. China too is a spatial fix for Africa's internal problems. TNCs and micro entrepreneurs across China and Africa must regard migration as a spatial fix too, according these neoclassical economists. In a sense, a case of a win-win 'migration for opportunity' is put by many mainstream economists, mainstream development institutions, and even humanists. Thus, whether migrants add to or take from the economy, the measure of progress is growth (see Clausing, 2019a, 2019b).

This is unsatisfactory. Original institutional economics can provide a more holistic view. The economy is judged more by its coherence, how it prevents social costs, 
supports the conditions of labour, and acknowledges ecological limits (Commons, 1907; Bromley and Anderson, 2012; Bromley, 2019; Abreu, 2012; Burnazoglu, 2017; Obeng-Odoom, 2018). With Marxist economics, the most visible opponent of neoclassical economics progressively riddled with what J.K Galbraith $(1977$, p. 7) called 'uncertainty' both in its critique and alternative policy proposals, it is a good time to consider the age-old contention - made by a wide range of institutional economists (e.g., Commons, 1907; Myrdal, 1944, 1968; Galbraith, 1977) - that original institutional economics theories can provide, perhaps, one effective alternative.

Table 2: Analytical Approach and How it Contrasts with the prevailing paradigm

\begin{tabular}{|c|c|c|}
\hline \multirow[t]{2}{*}{ Research Questions } & \multicolumn{2}{|c|}{ Analytical Paradigms } \\
\hline & Neoclassical Economics & $\begin{array}{ll}\text { Original } & \text { Institutional } \\
\text { Economics } & \end{array}$ \\
\hline Causes & $\begin{array}{l}\text { The free choices of utility- } \\
\text { maximising rational } \\
\text { migrants within the } \\
\text { individuals-centred push- } \\
\text { pull framework }\end{array}$ & $\begin{array}{l}\begin{array}{l}\text { Circular and } \\
\text { causation, }\end{array} \text { involving } \\
\text { transactions, institutions, } \\
\text { and individuals driven by } \\
\text { 'institutionalised minds' } \\
\text { not homo economicus } \\
\text { assumptions. }\end{array}$ \\
\hline Effects on the Economy & $\begin{array}{l}\text { The emphasis is on growth } \\
\text { and catch-up in an } \\
\text { economy that can expand } \\
\text { ad-infinitum without } \\
\text { systematic regard for } \\
\text { ecological limits, inequality, } \\
\text { or other social costs. }\end{array}$ & $\begin{array}{l}\text { Economic coherence, } \\
\text { entailing inclusive and } \\
\text { socio-ecologically } \\
\text { sustainable transformation } \\
\text { that is critically conscious } \\
\text { of ecological and } \\
\text { planetary limits. }\end{array}$ \\
\hline Migration Policy & $\begin{array}{l}\text { Focused primarily on } \\
\text { manipulating the state } \\
\text { (typically the government) } \\
\text { to ensure market } \\
\text { expansion, individual free } \\
\text { choices, and growth. }\end{array}$ & $\begin{array}{l}\text { Focused on a } \\
\text { comprehensive analysis of } \\
\text { a wide range of } \\
\text { institutions, including the } \\
\text { state (government, } \\
\text { legislature, judiciary, } \\
\text { media), banks, markets, } \\
\text { civil society temporally } \\
\text { and spatially. }\end{array}$ \\
\hline
\end{tabular}


Sources: Based on Commons, 1907, 1934a/2009, 1934b/2009; Myrdal, 1944, 1968; Galbraith, 1977; Bromley and Anderson, 2012; Bromley, 2019

This approach, described briefly in table 2, is far more comprehensive. Circular and cumulative causation recognises that causes are not linear, but circular, complex, combined, and cumulative, evolutionary and not necessarily the product of sudden change. This complexity is not merely additive as in vicious or virtuous circles utilised in mainstream economics, but rather cumulative, such that additional circles can have a much bigger thrust than previous circles. Interventions could change the patterns either upwardly or downwardly at any particular period, but the various cycles are not necessarily the same in force or power. The economy is, as Karl Polanyi (1957) noted, an 'instituted process'. Its formal meaning, centred on idealised living arrangements in which people act like atoms, that is, act alone to make reasoned rational choices for the maximisation of their own utility without considering other social relations, society, or environment, poorly reflects reality. Rather, the substantive meaning of the economy is more useful. Here, the emphasis is on actually existing livelihoods arrangement in which people depend on one another and collectively depend on the environment. The success of the economy, then, is to judged not so much in terms of growth, but also in terms of the conditions of labour, the trends in inequality, and the ramifications for wider society and environment. Attaining these hallmarks of the 'good economy' must be the preoccupation of the state which, interact with other institutions, including landed property rights, markets, and banks both spatially and temporally. Individual agency is, of course, important, but the individual mind is neither free floating or free standing. It is, according to J.R.Commons (1934a/2009; 1934b/2009), 'institutionalised', as it is transactional, that is, often shaped by its social relations, including conflicts.

The state too needs to be retheorised. According to J.R. Common:

The meaning of the word 'politics' has usually been limited to the activities designed to get control of what was deemed to be the dominant concern, the State. But with the modern emergence of innumerable forms of economic and moral concerted action, it is found that the similar complexity of personalities, principles, and organizations is found in all concerns. The fact that the sovereign concern uses the sanction of physical force has seemed to give dominance to it, as indicated by the word, 'sovereign'. But this is illusory, since, as we have seen, sovereignty has been the gradual, but incomplete, extraction of violence from private transactions, and other concerns dominate the state (Commons, 1934b/2009, p. 751).

So, the near exclusive focus on the Chinese Communist Party when analysing the Chinese state is limiting. So, is the neglect of other aspects of the state - including the judiciary - (Zhang and Elsner, 2017), especially as in both China and Africa, judiciary decisions increasingly impinge on society, economy, and environment (Obeng-Odoom and Gyampo, 2017; Fan and Lee, 2019; Zhao, 2019). Dissecting the Chinese state or African states in place, while neglecting their evolution over time is another limitation of existing research on Afro-labour migration. An evolutionary and historical critique of the state (legislature, executive, media, judiciary) that recognises 
that the state could simultaneously be a source of danger and potential, depending on the balance of interests that constitutes it and the actions and inactions of the other institutions that constitute 'collective action' within which the state is moulded.

This concerted action is also shaped by the nature of the individuals who make up the states. Such individuals are not necessarily selfish 'free agents' who are simply rent-seeking, as claimed by mainstream economists with interest in public choice theory. Rather they demonstrate a diversity of the 'institutionalised mind', partly shaped by local histories and contexts, partly moulded by prevailing global trends, and particularly shaped by interests, including whether the state in all its spheres (legislature, executive, media, judiciary) has been hijacked by landed interests.

Taking these matters into account, analysing Afro-Chinese labour migration is clearly important. Indeed, crucial in the current political-economic times, partly for verifying mainstream thinking, partly for contributing to migration policy, and particularly for retheorising the social economics of labour migration.

\section{References}

Abreu, Alexandre, 2012. 'The new economics of neoclassicals bearing', Forum for Social Economics, vol. 41, no. 1, pp. 46-67.

Aidoo R, 2010, 'China-Ghana Engagement: An alternative economic liberalization in Sub-Saharan Africa', PhD Dissertation, Miami University, Ohio, Oxford.

Akorsu A.D., 2010, 'Labour Standards Application in Ghana: Influences, Patterns and Solutions', A Thesis Submitted to the University of Manchester for the Degree of Doctor of Philosophy in the Faculty of Humanities, UK.

Akyeampong E, 2011, 'Africa, the Arabian Gulf, and Asia: Changing dynamics in contemporary West Africa's political economy', Journal of African Development, vol. 13, no. 1 , pp. 85-116.

Amoah LGA, 2014, 'China, architecture and Ghana's spaces: Concrete signs of a soft Chinese imperium?', Journal of Asian and African Affairs, vol 51, issue: 2, pp. 238-255. 
Amoah LGA, 2019, 'Six Decades of Ghanaian Statecraft and Asia Relations: Strategies, Strains and Successes' in Aryee J.R.A, ed, Politics, Governance, and Development in Ghana, Lexington Books, pp. 147-164.

Ancharaz V.D., 2011, 'China's Challenge to India's Economic Hegemony over Mauritius: A Tale of Two Giants and a Pigmy', Journal of African Development, vol. 13. Nos. 1 and 2, pp. 197-222.

Arrighi G, 2008, Adam Smith in Beijing: Lineages of the Twenty-First Century, Verso, London.

Axelsson L, 2012, 'Making Borders: Engaging the threat of Chinese textiles in Ghana', Stockholm University, Sweden, PhD thesis, Stockholm Studies in Human Geography

No. 22

Bara A, Mugano G, and Roux P.L., 2017, 'Spatial externalities, openness and financial development in the SADC', African Review of Economics and Finance, vol. 9, issue 1, pp. 245- 271.

Beck, J.H., 2012. 'Henry George and immigration'. Am. J. Econ. Sociol. 71 (no. 4),966-987.

Bodomo A.B. and Ma G, 2010, 'From Guangzhou to Yiwu: Emerging facets of the African Diaspora in China', International Journal of African Renaissance Studies Multi-, Inter- and Transdisciplinarity, vol. 5, no. 2, pp. 283-289.

Bodomo, A. B. 2012. Africans in China: A Socio-Cultural Study and its Implications on Africa-China Relations, Cambria Press, NY

Botchwey G, Crawford G, Loubere N, and Lu J, 2019, 'South-South irregular migration: The impacts of China's informal gold rush in Ghana', vol. 57, no. 4, International Migration, pp. $310-328$.

Bieler A and Lee C-Y, 2017, 'Chinese labour in the global economy: An introduction', in Bieler A and Lee C-Y, editors, Chinese Labour in the Global Economy: Capitalist Exploitation and Strategies of Resistance, Routledge, London, pp. 1-10. 
Brennan E.M., 1984, 'Irregular migration: Policy responses in Africa and Asia', The International Migration Review, vol. 18, no. 3, pp. $409-425$.

Bromley D.W. and Anderson G.D., 2012, Vulnerable People, Vulnerable States: Redefining the Development Challenge, Routledge, London and New York.

Bromley D.W. 2019, Possessive Individualism, Oxford University Press, Oxford.

Burnazoglu M, 2017, 'An identity-based matching theory approach to integration', Forum for Social Economics.

Cain A, 2014, 'African urban fantasies: past lessons and emerging realities', Environment \& Urbanization, vol 26(2): 561-567.

Castles, S. (2011). Migration, crisis and the global labour market. Globalizations, 8(3), 311-324

Castles, S. (2012). Migration, Crisis, and the Global Labour Market. In Ronaldo Munck, Carl Ulrik Schierup, Raul Delgado Wise (Eds.), Migration, Work and Citizenship in the New Global Order, (pp. 63-76). New York: Routledge.

Castles, S. (2015). Migration, Precarious Work, and Rights: Historical and Current Perspectives. In Carl-Ulrik Schierup, Ronaldo Munck, Branka Likic-Brboric, Anders.

Chang L, 2008, Factory Girls, Spiegel and Grau, New York.

Cheru F and Obi C, 2010, 'Introduction - Africa in the twenty-first century: strategic and development challenges', in Cheru F and Obi C, eds., The Rise of China and India in Africa, Zed, London, pp. 1-9.

Cheru F and Calais M, 2010, "Countering 'new imperialisms': what role for the new partnership for Africa's development?" in Cheru F and Obi C, eds., The Rise of China and India in Africa, Zed, London, pp. 221-237.

Cissé D, 2013, 'South-South migration and Sino-African small traders: A comparative study of Chinese in Senegal and Africans in China', African Review of Economics and Finance, vol. 5, no. 1, pp. 21-35. 
Cissé D, 2015, "African Traders in Yiwu: Their Trade Networks and Their Role in the Distribution of 'Made in China' Products in Africa", Journal of Pan-African Studies, vol.7, no.10, pp. 44-64.

Clausing K, 2019a, Open: The Progressive Case for Free Trade, Immigration, and Global Capital, Harvard University Press, Cambridge.

Clausing K, 2019b, 'The progressive case against protectionism: How trade and immigration help American workers', Foreign Affairs, vol. 98, no. 6, pp. 109-121.

Coles R, 1971, Migrants, Sharecroppers, Mountaineers, vol. II (Children of Crisis), Atlantic Monthly Press Book, Little, Brown and Company, Boston, Toronto.

Commons J. R, 1907, Races and Immigrants in America, The MacMillan Company, New York.

Commons JR (1934a/2009) Institutional economics: its place in political economy, vol 2. Transaction Publishers, New Brunswick and London.

Commons JR (1934b/2009) Institutional economics: its place in political economy, vol 2. Transaction Publishers, New Brunswick and London.

Daly H, 2019, 'A country of immigrants', Steady State Herald, February 4, https://steadystate.org/a-country-of-immigrants/ (accessed 30.12.2019).

Debrah E and Asante R, 2019, 'Sino-Ghana bilateral relations and Chinese migrants' illegal gold mining in Ghana', Asian Journal of Political Science, vol. 27, no. 3, pp. 286-307.

Duyyendak JJL, 1947, China's Discovery of Africa: Lectures Given at the University of London on January 22 and 23, Arthur Probsthain, London.

Edwards H.S., 2016, 'Beyond Walls: Why the forces of global migration can't be stopped', Time, February 4 and 11, pp. 24-46.

Fan $\mathrm{H}$ and Lee F.L.F., 2019, 'Judicial visibility under responsive authoritarianism: a study of the live broadcasting of court trials in China', Media, Culture and Society, vol. 41 , no. 8 , pp. $1088-1106$. 
French H.W. 2014, China's Second Continent: How a million Migrants are Building a New Empire in Africa, Alfred A Knopf, New York.

Freeman L, 2017, 'Environmental change, migration, and conflict in Africa: A critical examination of the interconnections', Journal of Environment and Development, pp. $1-24$.

Galbraith J.k., 1977, The Age of Uncertainty, Hougton Mifflin Company, Boston.

George, H.G., ([1886] 1991). Protection or Free Trade: An Examination of the Tariff Question, with Especial Regard to the Interests of Labor. New York: Robert Schalkenbach Foundation. http://schalkenbach.org/library/henrygeorge/ protectionor-free-trade/preface-index.html

Gordon M.M., 1961, 'Ethnic Groups in American Life', Daedalus, Vol. 90, No. 2, pp. 263-285

Graham-Harrison E and Garside J, 2019, 'Complete Control', The Guardian Weekly, pp. 10-11.

Haila, A., 2016. Urban Land Rent: Singapore as a Property State. Wiley Blackwell,Chichester.

Haifang L, 2010, 'China's development cooperation with Africa: historical and cultural perspectives', in Cheru F and Obi C, eds., The Rise of China and India in Africa, Zed, London, pp. 53-62.

Hart, K., 1973, 'Informal income opportunities and urban employment in Ghana', Journal of Modern African Studies, vol. 11, no. 1, pp. 61-89.

Harvey, D, 2006, Limits to Capital, Verso, London.

Henderson M, 2018, 'China's environment: Views from above, below, and beyond', Global Environmental Politics, vol. 18, no. 1, pp. 140-145.

Hilson G, Hilson A, and Adu-Darko E, 2014, 'Chinese participation in Ghana's informal gold mining economy: Drivers, implications and clarifications', Journal of Rural Studies, vol. 34, pp. 292-303.

Hobson J.M., 2004, The Eastern Origins of Western Civilisation, Cambridge University Press, Cambridge. 
HO C G-Y, 2012, 'Living in Liminality: Chinese Migrancy in Ghana', PhD thesis, University of California, USA.

Keynes J.M., 1953/1964, The General Theory of Employment, Interest, and Money, Harvest Books, Harcourt, Inc., San Diego, New York, and London.

Lemberg-Pedersen M, 2016, 'Review of Violent borders: Refugees and the right to move', Torture, vol. 28, no. 3, pp. 139-141.

McVeigh K and Dzradosi N, 2019, 'Ghana: Missing Fishermen', The Guardian Weekly, vol. 201, no. 25, pp. 26-27

Mutethya E, 2018, 'Bloom of youth', China Daily, Africa Weekly, vol. 7, no. 299, November 23-29.

Ngai P, 2016, Migrant Labor in China, Polity, London.

Jacobs, J., 1969, The economy of cities, Jonathan Cape Ltd, London.

Kapp K.W., 1950/1971, The Social Costs of Private Enterprise, Shocken Books, New York.

Lan S, 2015, 'State regulation of undocumented African migrants in China: A multiscalar analysis', Journal of Asian and African Studies, vol. 50, no. 3, pp. $289-304$.

Le D, 2016, 'Environmental and social risks of Chinese official development finance in Africa: The case of the Lamu Port Project, Kenya', African Review of Economics and Finance, vol. 8, no. 1, pp. 106-129.

Lee M, 2014, Africa's World Trade: Informal Economies and Globalisation, Zed Books, London.

Marcus E, 2017, Guangzhou Dream Factory, https://www.kanopystreaming.com/product/guangzhou-dream-factory (accessed 19.01.18). 
Mohan G, Lampert B, TAN-Mullins M, and Chang D, 2014, Chinese Migrants and Africa's Development: New Imperialists or Agents of Change? Zed, London.

Molero-Simarro R, 2017, 'Is China reaching the Lewis turning point? Agricultural prices, rural-urban migration and the labour share', Journal of Australian Political Economy, no. 78, Spring, pp. 48-86.

Molotch H, 1976, 'The City as a Growth Machine: Toward a Political Economy of Place', American Journal of Sociology, Vol. 82, No. 2, pp. 309-332.

Mung, Emmanuel Ma, 2008, 'Chinese Migration and China's Foreign Policy in Africa', Journal of Chinese Overseas, vol. 4 no. 1, 2008, pp. 91-109

Myrdal, G., 1944, An American dilemma: The negro problem and modern democracy, Harper and Brothers Publishers, New York.

Myrdal G, 1968, Asian Drama: An Inquiry into the Poverty of Nations, vol. III, Pantheon, New York.

Ndjio B, 2009, “'Shanghai Beauties' and African Desires: Migration, Trade and Chinese Prostitution in Cameroon", European Journal of Development Research, vol. 21, 606-621

Ndjio B, 2014 "'Magic body' and 'cursed sex': Chinese sex workers as 'bitchwitches' in Cameroon", African Affairs, vol. 113, no. 452, pp. 370-386.

New African Magazine, 2015, 'China's long history in Africa', New African Magazine, 11 March, http://newafricanmagazine.com/chinas-long-history-africal (accessed 20. 07. 17).

Obeng-Odoom F, 2011, 'The informal sector in Ghana under siege', Journal of Developing Societies, vol.27, no.3 and 4, pp.355-392.

Obeng-Odoom F, 2013, Governance for Pro-Poor Urban Development: Lessons from Ghana, Routledge, London.

Obeng-Odoom F, 2014, Oiling the Urban Economy: Land, Labour, Capital, and the State in Sekondi-Takoradi, Ghana, Routledge, London.

Obeng-Odoom F and Gyampo R.E.V., 2017, 'Land grabbing, land rights, and the role of the courts', Geography Research Forum, vol. 31, December. pp. 127-147. 
Obeng-Odoom F, 2015, 'The social, spatial, and economic roots of urban inequality in Africa: Contextualizing Jane Jacobs and Henry George', The American Journal of Economics and Sociology, vol. 74, no. 3., pp. 550-586.

Obeng-Odoom F, 2016, Reconstructing Urban Economics: Towards a Political Economy of the Built Environment, Zed, London.

Obeng-Odoom F, 2017, 'Unequal access to land and the current migration crisis', Land Use Policy, vol.62, March, pp. 159-171.

Obeng-Odoom F, 2018, 'The contribution of J.R. Commons to migration analysis', Evolutionary and Institutional Economics Review vol.15, no. 1, pp. 73-88.

Ozkul D and Obeng-Odoom F, 2013, 'Temporary migration in Africa: Views from the Global South', African Review of Economics and Finance, vol. 5, no. 1, pp. 1-6.

Park J.P., Lampert B, Robertson W, 2016, 'Editorial: China's impacts on Africa's development', African Review of Economics and Finance, vol. 8, issue 1, pp. 3-11.

Park Y.J., 2019, 'Early Chinese Migrants in Sub-Saharan Africa: Contract Labourers and Traders' Chinese and African Entrepreneurs', in Giese K and Marfaing L, eds., Chinese and African Entrepreneurs Social Impacts of Interpersonal Encounters, Brill, Leiden, pp. 84-99

Pishé V, 2013, 'Contemporary Migration Theories as Reflected in their Founding Texts', Population-E, 68 (1), 2013, 141-164.

Polanyi K, 1957, 'The economy as instituted process', in Polanyi K, Arensberg C.M., and Pearson H.W., eds., Trade and Market in the Early Empires: Economies in History and Theory, The Free Press Glencose, Illinois, pp. 243-270.

Polanyi K, [1944] 2001, The Great Transformation: The Political and Economic Origins of Our Time, Beacon Press, Massachusetts.

Ramazzotti P, Frigato P, Elsner W, 2012, Social Costs Today: Institutional Analyses of the Present Crisis, Routledge, London.

Ramamurti R and Hillemann J, 2018, "What is 'Chinese' about Chinese multinationals?", Journal of International Business Studies, vol. 49, pp. 43-44.

Ravenstein, Ernst.Georg. 1885. 'The Laws of Migration', Journal of the Royal Statistical Society 48:167-235 Series: Economics and Organization, 8 (4):345-356.

Ravenstein Ernst.Georg, 1889, 'The laws of migration', J. R. Stati. Soc. 52 (2),241305.

Robertson W, 2016, 'Review of China's Superbank: Debt, Oil and Influence - How China Development Bank is Rewriting the Rules of Finance', African Review of Economics and Finance, vol. 8, issue 1, pp. $164-167$. 
Rosewarne, S., 2010. Globalisation and the commodification of labour: temporary labour migration. Economic and Labour Relations Review, vol. 20, no. 2, pp. 99-110.

Rosewarne, Stuart, 2012. Temporary international labor migration and development in south and Southeast Asia. Feminist Econ. 18 (2), 63-90.

Rosewarne, S., 2014. 'Migrant domestic work: from precarious to precarisation', J.fuer Entwicklungspolitik (Aust. J. Dev. Stud.), 30 (4), 133-154.

Rosewarne, S., 2016. 'Transnationalization and the capitalization of labor: female foreign domestic workers', In: Zahra Meghani (Ed.), Women Migrant Workers: Ethical, Political and Legal Problems. Oxford, Routledge, pp. 199-223.

Sanderson H and Forsythe M, 2013, China's Superbank: Debt, Oil and InfluenceHow China Development Bank is Rewriting the Rules of Finance, John Wiley and Sons, Singapore.

Saunavaara J, 2017, 'The role of international development strategies in making regional development policies: Hokkaido as a case study', Urbani Izziv, vol. 28, no. 2, pp. $122-135$.

Schumpeter J.A., 1947, 'The Creative Response in Economic History', The Journal of Economic History, Vol. 7, No. 2, pp. 149-159

Sheridan D, 2016, "Review of 'China's Second Continent: How a million migrants are building a new empire in Africa", African Review of Economics and Finance, vol. 8, issue 1 , pp. 156-159.

Tinti P and Reitano T, 2017, Migrant, Refugee, Smuggler, Savior, Oxford University Press, New York.

The Economist, 2019a, 'The new scramble for Africa', The Economist, March $9^{\text {th }}-$ $15^{\text {th }}$, p.9.

The Economist, 2019b, 'Silk Rhodes', The Economist, January $26^{\text {th }}$ - February $1^{\text {st }}$, pp. 49-50.

The Economist, 2019c, 'The magic of migration', The Economist, November $16^{\text {th }}$ 22 $2^{\text {nd }}$, pp. 3-12. 
The Economist, 2019d, 'Choices on the continent', The Economist, March $9^{\text {th }}-15^{\text {th }}$, pp.18-20.

The Economist, 2019e, 'Workers' Pay: Keeping caps out of hands', The Economist, December 21st $-3^{\text {rd }}$ January, pp.81-82.

Thornton P, 2014, 'Chinese miners and Ghana's golden reform opportunity', International Growth Centre, September 24.

Todaro, Paul, Michael, 1969. 'A model of labor migration and urban unemployment in less developed countries'. Am. Econ. Rev. 59 (1), 138-148.

Todaro, Michael Paul, Stephen, Smith, 2006. Economic development. Pearson Addison Wesley London.

Tonah S, Setrana M.B., and Arthur J.A., 2018, Migration and Development in Africa: Trends, Challenges, and Policy Implications, Lexington Books, New York.

Tremann C, 2013, 'Temporary Chinese migration to Madagascar: Local perceptions, economic impacts, and human capital flows', African Review of Economics and Finance, vol. 5, no. 1, pp. 9-20.

Wang Y, 2019, Pseudo-Public Spaces in Chinese Shopping Malls: Rise, Publicness and Consequences, Routledge, London.

Wang, ZH Giovanis E, 2019, An Evolutionary Model of Adaptation, Selection, and Replication in Expatriation. Journal of Economics Theory.

Watson, V (2014), "African urban fantasies: dreams or nightmares?", Environment and Urbanization, vol 26, No 1, pp. 215-231.

Whitaker B.E., 2017, 'Migration within Africa and beyond', Africa Studies Review, vol. 60, no. 2, pp. 209-220.

Wilson J, 2015, 'The village that turned to gold: A parable of philanthrocapitalism', Development and Change, pp. 1-26. 
World Bank, 2017, Migrating to Opportunity Overcoming Barriers to Labor Mobility in Southeast Asia, World Bank, Washington DC.

Xu Z and Chen Y, 2019, 'Spatial shift in China's labor struggles: Evidence and implication', Journal of Labor and Society, vol. 22, pp. 129-138.

Zhang Y., \& Elsner, W. (2017). 'A social-leverage mechanism on the Silk Road: The private emergence of institutions in central Asia, from the 7th to the 9th century', Journal of Institutional Economics, 13(2), 379-400.

Zhao Y, 2019, 'The way to understand the nature and extent of judicial independence in China', Asian Journal of Law and Society, vol. 6, pp. 131-157.

i 'Ghana requires US $\$ 650$ billion to reclaim environment - Prof. Frimpong Boateng', Peacefmonline.com/pages/local/social/201801/341752.php (accessed 23.01.18). 